浴皮膜の順序となった。

また, 硫酸薄膜とフッ化アンモニウムーアンモニア系浴 薄膜に対するハロゲンイオンの通過性について検討を行 なった結果はつぎのとおりである。

4) 薄膜の種類にかかわらずハロゲンイオンの通過量 は塩素>フッ素>臭素イオンの順序となった。また, フ ッ化アンモニウムーアンモニア系浴薄膜では硫酸薄膜に 比べ通過量が大きい。

5) フッ素イオンは酸性では吸着量の減少がみられ る。

金属フッ化物の皮膜に対する影響について検討を行な いつぎのよらな結論を得た。

$1^{\prime}$ ) 硫酸皮膜に対し金属フッ化物の一部（フッ化リチ ウム, フッ化マンガン, フッ化亜鉛, フッ化コバルト， フッ化ニッケル，フッ化クロム）飞封孔性がみられ，と くにフッ化クロム，フッ化ニッケルにその効果が大であ
った。フッ化アンモニウムーアンモニア系浴皮膜では封 孔性は認められなかった。

$2^{\prime}$ ) 金属フッ化物法に括いて，その封孔性（反応性） は皮膜に対するハロゲンイオンの吸着と同様に濃度が 大, 液温の上昇, $\mathrm{pH}$ が酸性となると大きい。また，フ ッ素イオンの共存が封孔効果を増加させる。

$3^{\prime}$ ) 金属フッ化物による適当処理条件は大約濃度：

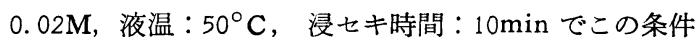

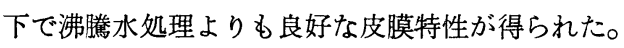

(1973-9-14 受理)
文献
1) 吉村長藏, 本誌, 23, 440 (1972)
2）馬場宣良, 本誌, 24, 34 (1973)
3 ) 石橋雅義, 分析化学, 20, 749 (1971)
4 ) 吉村長藏, 本誌, 22, 568 (1971)

\title{
電着塗料共存下におけるアルミニウムの 陽極酸化について†
}

\author{
吉村長蔵*・野口駿雄* ・小沢和裕*

\section{Anodizing of Aluminum in the Presence of Electrodeposition Paint} \\ Studies on Finishing of Aluminum in Alkaline Media (Part 9) \\ Chozo YOSHIMURA, Hayao NOGUCHI and Kazuhiro OZAWA
}

The present investigation relates to the electrophoretic deposition of a water soluble paint on aluminum film, which is simultaneously anodized in an alkaline (triethanolamine or ammonium hydroxide) solution. The following two kinds of solutions were used for electrolytic baths. (1) About $0.3 \%$ solution of an electrodeposition paint containing ammonium hydroxide $(2 \mathrm{~mol})$, ammonium tartrate $(0.1 \mathrm{~mol})$, ammonium fluoride $(0.3 \mathrm{~mol})$, and ammonium carbonate $(0.1 \mathrm{~mol})$. (2) About $2 \%$ solution of the same paint as in (1) containing triethanolamine $(1 \mathrm{~mol})$, ammonium fluoride $(0.1 \mathrm{~mol})$, and tetramethyl ammonium hydroxide $(0.2 \mathrm{~mol})$. As the results of anodizing in above solution (1), a film obtained by two-step electrolysis (i. e., anodizing for $15 \mathrm{~min}$. under D. C. of $4 \mathrm{Amp} / \mathrm{dm}^{2}$ and then, anodizing again for $35 \mathrm{~min}$. under D. C. of $2 \mathrm{Amp} / \mathrm{dm}^{2}$ ) was about $35 \mu$ in thickness, which was thicker than a film (about $27 \mu$ in thickness) formed in the solution containing no electrodeposition paint. On the other hand, in above solution (2), a film (11 $\mu$ in thickness) was formed by electrolysis for $60 \mathrm{~min}$. under D. C. of $2 \mathrm{Amp} / \mathrm{dm}^{2}$. The results of thermal analysis, infrared spectroscopic analysis, and microscopic examination showed that the paint which had been dissolved in the bath was contained in the film obtained, which is called "a simultaneous electrodeposition film". It was observed

†アルミニウムのアルカリ性浴処理法の研究 (第 9 報), 前報 (第 8 報)：25, 126 (1974)

* 近畿大学理工学部応用化学科 (大阪府東大阪市小若江321)

Department of Applied Chemistry. Faculty of Science and Engineering. Kinki University. 
that the amount of paint contained in the film anodized in above solution (2) (measured value 36\%) was greater than that anodized in above solution (1) (measured value 12\%). Therefore, the film formed in above solution (2) had very higher alkali resistace (to $10 \% \mathrm{NaOH}$ ) and higher scratch hardness (by Martens' hardness tester with a load of $50 \mathrm{~g}$ ) than the film anodized in the same alkaline bath containing no paint.

\section{1. 緒}

アルミニウムを保護し, 耐酸, 耐アルカリ性および耐 摩耗性を向上させる一方法として塗装が行なわれてお りなかんずく最近は，電着塗装（電気泳動塗装）また は静電塗装などが盛んに行なわれている。電着塗装は陽 極酸化皮膜上への二次電着が行なわれているが，この方 法では陽極酸化後さらに塗料浴中で電着を行ならために 時間のロスや設備の面よりの問題がある。また，電着浴 への酸の持ち込みの防止, 液管理などが複雑である。ゆ えに本報では，市販電着塗料が良く溶解すると思われる アミンアルカリ性浴豆扣よびアンモニアアルカリ性浴 ${ }^{2}$ を用い，この浴に市販電着塗料を共存させて陽極酸化を 行ない，酸化皮膜を生成させると同時に塗料の同次電着 を試みた。

\section{2. 実験方法}

\section{2-1 電解浴組成}

次表に示した各浴 $1 l$ に対して，アンモニアアルカリ 性浴の場合は，市販電着塗料を $3 \mathrm{~g}$ ，アミンアルカリ性 浴の場合は20 g を溶解させて用いた。また，電着塗料を 共存させた場合と比較するために，電着塗料を溶解して いない浴をも用いた。

塗料を共存させて電解を行なった場合について，以下 同時電着塗装といい，生成した皮膜を同時電着皮膜と称 し，これに対して塗料を共存していない浴中で生成した 皮膜を, アンモニアアルカリ性皮膜拁よびアミンアルカ リ性皮膜と略称する。

アンモニアアルカリ性浴

\begin{tabular}{cl}
\hline 浴 組 成 & 濃 度 \\
\hline アンモニア水 & $2.3 \mathrm{M}$ \\
酒石酸アンモニウム & $0.1 \mathrm{M}$ \\
フッ化アンモニウム & $0.27 \mathrm{M}$ \\
炭酸アンモニウム & $0.1 \mathrm{M}$ \\
\hline
\end{tabular}

アミンアルカリ性浴

\begin{tabular}{cl}
\hline \hline 浴 組 成 & 濃 度 \\
\hline トリエタノールアミン & $1 \mathrm{M}$ \\
テトラメチルアンモニウム & $0.16 \mathrm{M}$ \\
ハイドロキサイド* & \\
フッ化アンモニウム & $0.08 \mathrm{M}$ \\
\hline \hline
\end{tabular}

* 以下第四アンモニウム塩と略す

\section{2-2 電解条件}

2-2-1 アンモニアアルカリ性浴の場合

浴温度を $20 \pm 1{ }^{\circ} \mathrm{C}$ に保ち，つぎの両者の方法で電解 を行なった。

（1）電流密度を $2 \mathrm{~A} / \mathrm{dm}^{2}$ として $30 \mathrm{~min}$ 陽極酸化を 行なった後,さらに電流密度を $3.8 \mathrm{~A} / \mathrm{dm}^{2}$ に変えて引き 続き $15 \mathrm{~min}$ 電解を行なった。以下，この方法を二段電解 法 (I ) という。（2）電流密度を $3.8 \mathrm{~A} / \mathrm{dm}^{2}$ として15 min陽極酸化を行なった後,さらに電流密度を $2 \mathrm{~A} / \mathrm{dm}^{2}$ に 下げて陽極酸化を行なった。以下，この方法を二段電解 法（II）という。

2-2-2 アミンアルカリ性浴の場合

浴温度を $25 \pm 1{ }^{\circ} \mathrm{C}$ に保ち，カクハンしながら塗料が 共存している場合は, 初期電流密度を $2 \mathrm{~A} / \mathrm{dm}^{2}$ (100 $110 \mathrm{~V})$ とし，また，塗料が共存していない場合は，初 期電流密度を $2 \mathrm{~A} / \mathrm{dm}^{2}(60 \sim 65 \mathrm{~V})$ として陽極酸化を行 なった。なおカクハンはマグネティックスタラーを使用 した。

\section{2-3 アルミニウム試験片および対極}

$99.85 \%$ 純アルミニウム $(3 \times 5 \times 0.04 \mathrm{~cm})$ を使用 し，常法により脱脂を行なった。対極にはステンレス鋼 （アルミニウムと同面積）を用いた。

\section{2-4 後処理}

同時電着塗装を行なった皮膜は，温度 $160 \sim 170^{\circ} \mathrm{C}$ で 1 h焼付ケを行なった。

\section{2-5 皮膜試験法}

2-5-1 膜厚およびカタサ測定法

膜厚測定はパーマスコープならびに顕微鏡により行な った。カタサはマルテンス式ヒッカキカタサ試験器（荷 重50g）により行なった。

\section{2-5一2 耐アルカリ性試験法}

（1）浸七キ法， $10 \%$ 水酸化ナトリウム溶液を $20^{\circ} \mathrm{C}$ に保ち， $3 \mathrm{~min}$ 浸セキした後りン酸一クロム酸液に浸セキ し, 各試験片の皮膜の重量を求め, 上記水酸化ナトリウ ム溶液に対する溶解量を測定した。（2）滴下法，JIS 8601にしたがい行なった。

2-5-3 電子顕微鏡試料作成法

二段レプリカ法で試料を作成し，スーパースコープ （日本電子秼製JEM-30C型）により観察した。

\section{2-6 皮膜中の塗料の確認法および皮膜のハク離法}

示差熱分析器 (理学電機製, No. 8001), 熱テンビン 


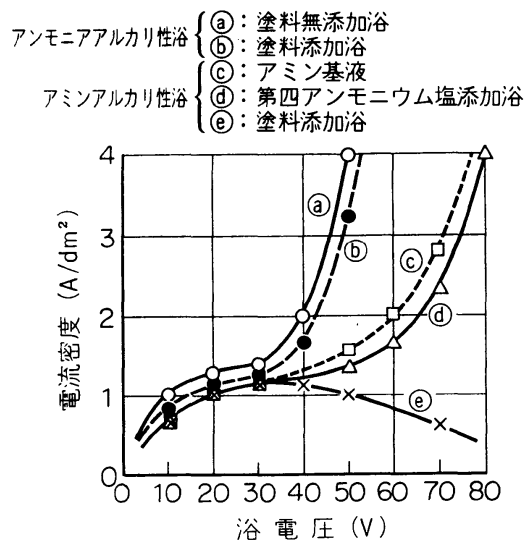

図1アンモニアおよびアミンアルカリ性 浴での電流一電圧曲線

（長計量器製 VDSPSH-26）および赤外分光光度計（柳 本製作所製ISG-25型）を使用し，生成した皮膜をガラス 片でハク離し，これを試料として塗料の存在の有無を検 討した。

\section{3. 実験結果および考察}

\section{3-1 電流-電王曲線}

アンモニアアルカリ性浴の場 合:

塗料の共存していない場合抽 よび塗料の共存している場合 （図 1 @执よび(b）ともに，電 圧が増加するにしたがって電流 值も上昇したが, 電圧約 $10 〜 25$ $\mathrm{V}$ をて電流值の上昇は少なかっ た。

アミンアルカリ性浴の場合：

トリエタノールアミン（20 \%) およびフッ化アンモニウム (0.08M)（以下，アミン基液と 略す), これに第四アンモニウ ム塩を添加した場合およびさら に塗料を共存させて測定した結 果 (図 1 (C), @㧊よび(e), 塗 料を添加しない場合は, アンモ ニアアルカリ性浴の曲線に類似 し，塗料が共存した場合は，35 〜 40Vまで電流值は徐々に増加 したが，それ以上の電圧では逆 に低下した。

\section{3-2 電流値の経時変化}

アンモニアアルカリ性浴の場
合：

二段電解法（I）を図 2 （i ） に，二段電解法（II） を図 2 (ii) に示した。

アミンアルカリ性浴の場合 :

アミン基液の場合は， $2 \mathrm{~A} / \mathrm{dm}^{2}$ (60 V) で，第四アン モニウム塩を添加した場合および電着塗料を共存させた 場合は， $2 \mathrm{~A} / \mathrm{dm}^{2}(64 \mathrm{~V}$ ) で陽極酸化を行ない，それぞ れの結果を図 2 (iii) に示した。

\section{3-3 膜厚と電解時間との関係}

3-3-1 アンモニアアルカリ性浴

二段電解法（I）の結果を図 3 （i ）に示した。 30 minまでは $2 \mathrm{~A} / \mathrm{dm}^{2}$ で電解を行なった場合の膜厚増加を 示し, それ以後は3. $8 \mathrm{~A} / \mathrm{dm}^{2}$ に上昇させて陽極酸化した 場合の膜厚增加を示す。

塗料が共存していない場合は, $2 \mathrm{~A} / \mathrm{dm}^{2}, 30 \mathrm{~min} て ゙$ $14.5 \mu$, さらに3. $8 \mathrm{~A} / \mathrm{dm}^{2}, 15 \mathrm{~min}$ 電解で $12.5 \mu$ の膜厚 増加を示し, 全膜厚 $27 \mu$ を得た。塗料を共存させた場合 は，同様に最初の電解で $15 \mu$ を，つぎに $16 \mu$ の膜厚増 加を示し，前者に比べて約 $4 \mu$ 厚い皮膜 $(31 \mu)$ を得 た。

二重電解法（II）の結果を図 3 (ii) に示した。塗料

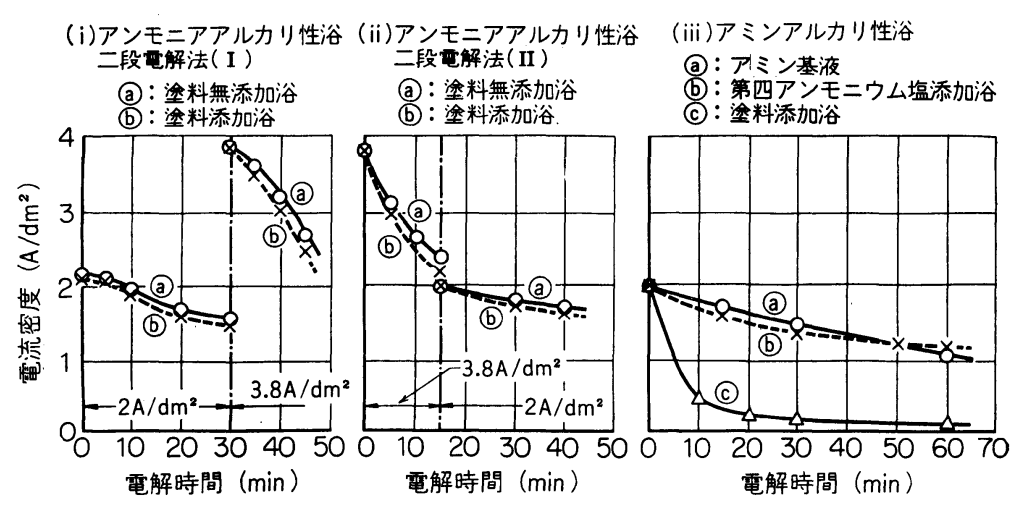

図 2 電流值の経時変化

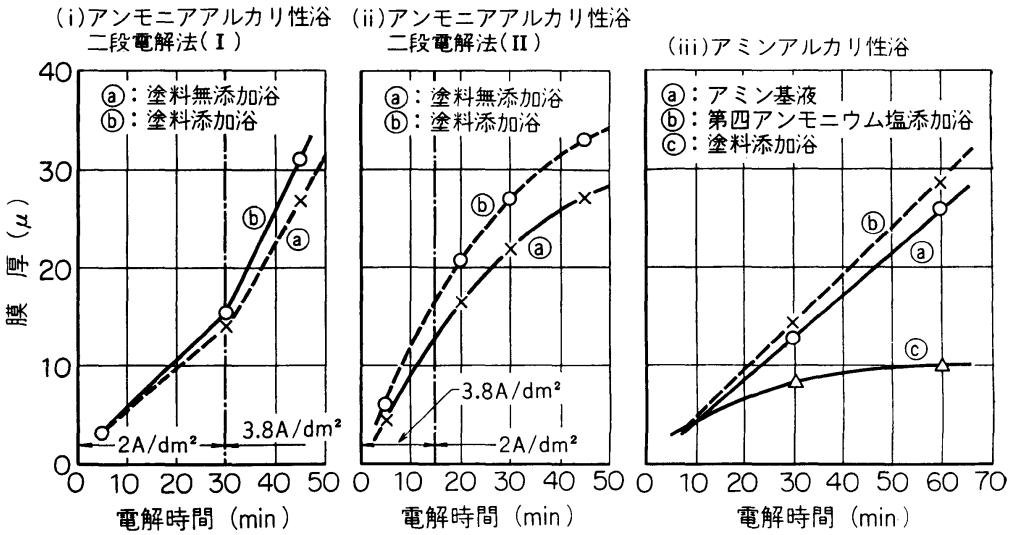

図 3 電解時間之膜厚との関係 


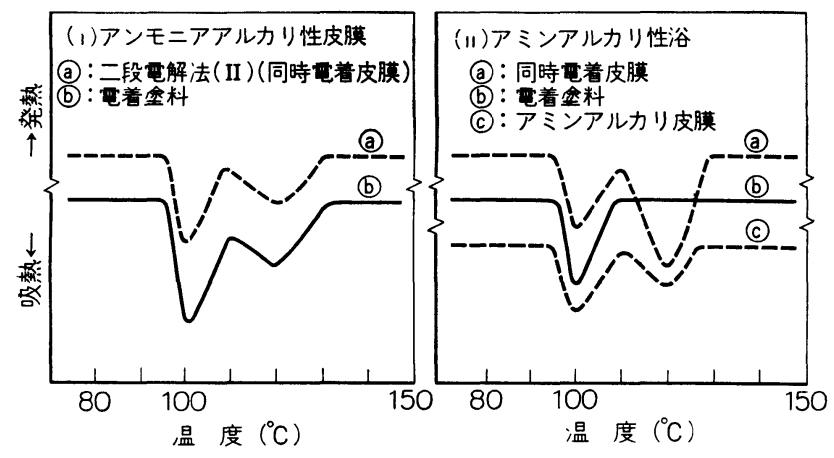

図 4 示差熱分析結果

が共存していない場合および共存している場合ともに， 二重電解法（I）の場合の全膜厚とほとんど同じであっ た。上記二法ともに，塗料が共存している場合のほうが 厚い皮膜を生成した。3-2で述べた電流值の経時变化の 測定結果から, 塗料が共存している場合は, 塗料の共存 していない場合に比較して，電流值の低下程度が大きい ことより，塗料共存浴中で生成した皮膜中に塗料が含ま れていると推定される。

\section{3-3-2 アミンアルカリ性浴}

結果を図3（iii）に示した。アミン基液の場合は 2 $\mathrm{A} / \mathrm{dm}^{2}$ (60V)，第四アンモニウム塩を添加した浴の場 合および塗料を共存させた場合は，2 A/ $\mathrm{dm}^{2}$ (64 V) で $60 \mathrm{~min}$ 陽極酸化を行なった結果である。それぞれ $26 \mu$, $28 \mu$ および11 $\mu$ の膜厚を得た。

\section{3-4 熱分析結果}

3-4-1 アンモニアアルカリ性浴の場合

塗料共存下, アンモニアアルカリ性浴中で, 二段電解 法（II）で陽極酸化を行なった皮膜を $48 \mathrm{~h}$ 真空乾燥させ た後, ガラス片を用いて皮膜をハク離し, 示差熱分析を

表 1 電解時間と皮膜中の塗料と酸化皮膜との割合

\begin{tabular}{c|c|c|c}
\hline $\begin{array}{c}\text { 電解時間 } \\
(\mathrm{min})\end{array}$ & $\begin{array}{c}\text { 塗料添加量 } \\
(\%)\end{array}$ & $\begin{array}{c}\text { 塗 } \\
(\%)\end{array}$ & $\begin{array}{c}\text { 料酸化皮膜 } \\
(\%)\end{array}$ \\
\hline 60 & 2 & 69.4 & 30.5 \\
\hline 30 & 0.4 & 28.4 & 71.6 \\
\hline 2 & 59.1 & 40.9 \\
\hline 15 & 0.4 & 20.7 & 79.3 \\
\hline 10 & 2 & 41.8 & 58.2 \\
\hline 5 & 2 & 14.2 & 85.8 \\
\hline \hline
\end{tabular}

アミンアルカリ性浴

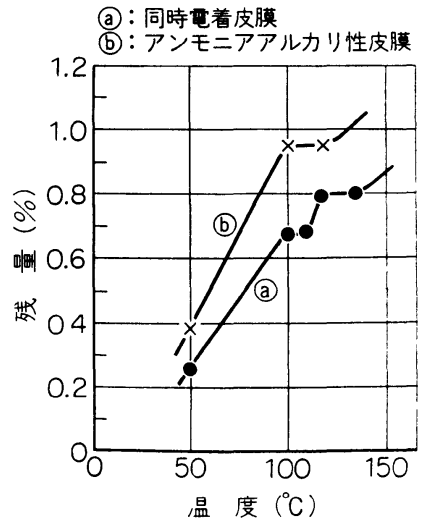

図 5 アンモニアアルカリ性浴中て生成 した皮膜の熱分解曲線

行なった。結果を図4（i）（の曲線に示しだ。電着塗 料のみを真空乾燥した後の結果をゆに示した。電着塗料 は水分の影響のために $100^{\circ} \mathrm{C}$ で吸熱反応を起こし，118 Cで塗料による吸熱反応が観察された。同時電着皮膜に ついても同じ温度で吸熱反応が観察され，皮膜中に塗料 が含まれていることが推定されだ。また，熱テンビンに よる分解曲線（図 5) 女, 上記示差熱分析の結果と一致 した。

すなわち, 塗料が共存していない場合の酸化皮膜の結 果を(ゆに，同時電着皮膜の結果を@に示したが，同時電 着皮膜の場合は $120^{\circ} \mathrm{C}$ 付近で重量減少が認められた。

3-4-2 アミンアルカリ性浴の場合

第四アンモニウム塩および塗料を共存させた浴を用い て得られた皮膜をハク離し，3-4-1 の場合と同様に乾 燥して示差熱分析を行なった。その結果を図4（ii）に 示した。同時電着皮膜および電着塗料は， $120^{\circ} \mathrm{C}$ 付近に 吸熱反応が認められた。

\section{3-5 赤外吸収曲線}

電着塗料のみの赤外吸収曲線を ${ }^{3)}$ 図 6 @に示した。 2995 2850 $\mathrm{cm}^{-1}$ に $\mathrm{CH}_{3}, \mathrm{CH}_{2}$ のC-H 伸縮振動, 1730 $\mathrm{cm}^{-1}$ にエステルの $\mathrm{C}=0$ 伸縮振動, $1300 \sim 1000 \mathrm{~cm}^{-1}$ 付 近にカルボン酸またはカルボン酸エステルと思われる吸 収が認められた。

アミンアルカリ性皮膜およびアミンアルカリ性浴中で 得られた同時電着皮膜の赤外吸収曲線をそれぞれ図 6 (b および@に示したが，明らかに同時電着皮膜中に塗料が 含有されていることが認められた。

\section{3一6 アミンアルカリ性浴での塗料の荟度による影郘} 塗料の濃度を $0.4 \%$ と $2 \%$ との両者につき検討した。 3-6-1 同時電着皮膜中の酸化皮膜と塗膜との生 成 率について

$0.4 \%$ おび $2 \%$ 塗料を含有するアミンアルカリ性 


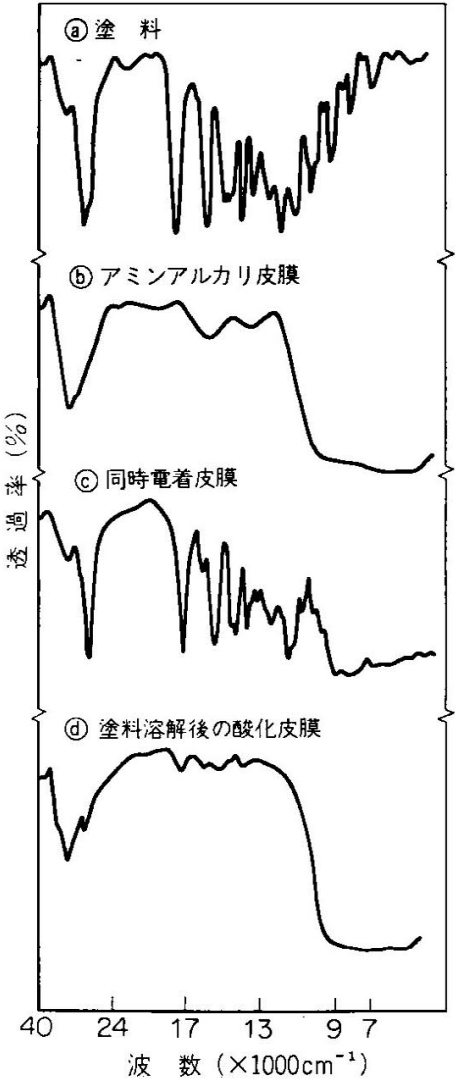

图 6 赤外吸収曲線

浴中で得られた同時電着皮膜を， $\mathrm{N}-\mathrm{N}^{\prime}$ ジメチルホルム アミド (DMF) とメタノールの混液 $(1: 1)$ に h 浸セキして電着された叙料を溶解した後, リン酸ーク口 么酸混液中で酸化皮膜を溶解させて皮膜の重量を求め， 同時電着皮膜中の塗料と酸化皮膜の㓶合を求めた。電解 時間之叙料拉よび酸化皮膜の割合について，0.4\%塗料 含有浴使用の場合および $2 \%$ 渗料含有浴使用の場合を表 1 亿示した。1 hの電解により生成した同時電着皮膜中 の塗料の含有率は，0.4\%の場合, 約 $28 \% ， 2 \%$ 場合 は, 約69\%であった。

$3-6-2$ 電解時間と塗料の膜厚と酸化皮膜の膜厚と の関係

塗料を添加したアミンアルカリ性浴中で，種々時間を 変劣て陽㯹酸化を行ない，それぞれの試験片をDMFーメ タノール混液に浸せキし，塗料を溶解後の皮膜の厚サを 求め, 電解時間との関係を求めた。

$0.4 \%$ 塗料が共存している浴を用いて得られた同 時 電着皮膜の全膜厚@と塗料を溶解した酸化皮膜の膜厚(D と電解時間との関係を図7（i）に示した。同様に $2 \%$ の塗料を涯加した場合の結果を図 7 (ii) に示した。
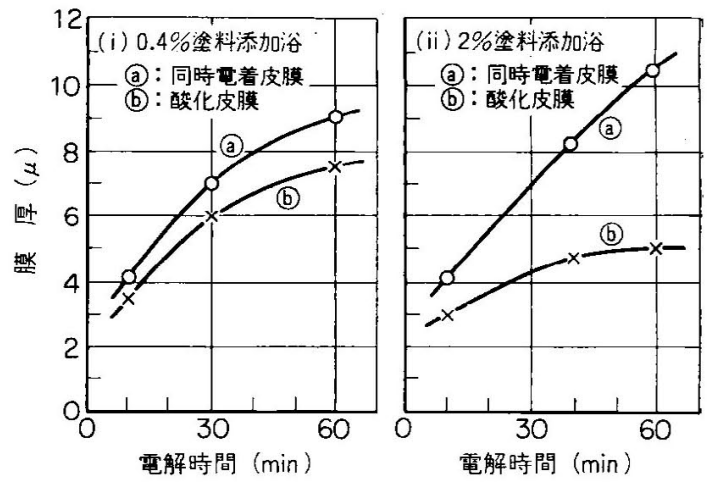

図7フミンアルカリ性浴での同時電着皮膜および 酸化皮膜厚サと電解時間との関倸

\section{3-7 塗料溶解後の皮膜の赤外吸収曲線}

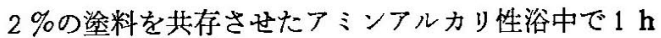
陽極酸化を行ない，生成した皮膜をDMF-メタノール混 合液中に浸七キし，塗料を溶解させた後，残りの皮膜を ガラス片でハク離し，赤外吸収曲線を求めた。その結果 走图 6 (dに示す。先に述べ酸化皮膜の赤外吸収曲線叔 上び電着涂料の吸收曲線（図 6 (b)抒よび図 6 @）と比較 した結果， C-Hの伸縮振動， $\mathrm{C}=0$ の伸縮振動が少しく 認ぬられ，酸化皮膜中にも少量の鉒料が含有されている と考えられる。

\section{3-8 顕微錛による観察結果}

3-8-1 同時奄着皮膜の断面観察結果

アミンアルカリ性浴中に $2 \%$ 塗料を共存させた場合 の皮膜の断面を，金属顕微蹱を用いて400 倍で観察した。 その結果, 写真 1 に示したように断面忹 2 層に分かれ， 表面が塗料の層で，アルミ素地側が酸化皮膜層であると 考学られる。1 hの電解により生成した皮膜の塗料の層

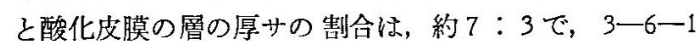
の結果と一致した。

3-8-2 電子顕徽鏡による表面観察結果

アミンアルカリ性皮膜の表面, 同時電着皮膜 (アミン アルカリ性）扣よび同時電着皮膜の塗料をDMFーィタノ

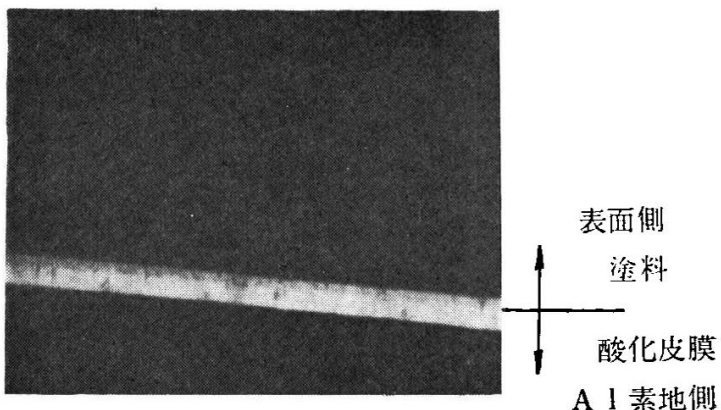

写真 1 同時電着皮膜の断面（アミンアルカリ性） 
一ル混合溶液に溶解した後の表面を観察し，それぞれの 䉓子频微鏡 (×2000) を, 写真 2 @，写真 2 (おおよび写 真 2 @示した。これらの顕微鏡写真より, 染料が步存 していない浴中で得られた皮膜に比較して, 塗料が共存 している浴中で得られた皮膜の表面はなめらかであっ た。をた, 同時電着皮膜より塗料を溶解させた後の表面 は, 非常に凹凸が激しく、これらのことより酸化皮膜生 成と同時にごく少量の鈖料が含有され，膜厚が増加する にしたがって電解電厈が上昇し，塗料の泳動が大にな り，やがて酸化皮膜の生成が少なくなり塗料が大量表面 に電着されると考克られる。したがって，図 2 (iii) (c) のよらな曲線が得られたものと考えられる。

\section{3一9 ヒッカキカタサおよび耐アルカリ性試験結果}

3一9-1 アンモニアアルカリ性浴の場合

二段電解法 (I ) ( $2 \mathrm{~A} / \mathrm{dm}^{2}, 30 \mathrm{~min}$ 後 $3.8 \mathrm{~A} / \mathrm{dm}^{2}, 15$ min) 特よび（II） $\left(3.8 \mathrm{~A} / \mathrm{dm}^{2}, 15 \mathrm{~min}\right.$ 後 $2 \mathrm{~A} / \mathrm{dm}^{2}, 30$ min）の両者につき，塗料の共存していない場合および 塗料の共存している場合に生成した皮膜について比較し た。その結果，表 2 に示したよらに，いずれも同時電着 皮膜がすぐれた結果を得た。また，二段電解法（I）に
比較して，二段電解法（II）がややすぐれた結果を得 た。

\section{3一9—2 アミンアルカリ性浴}

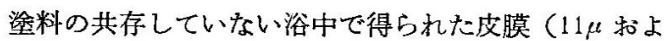
$ひ ゙ 4 \mu)$ と, 同時電着皮膜 $(11 \mu)$ 括上び同時電着皮膜 の塗料を溶解した後の酸化皮膜 $(4 \mu)$ の四者について 比較した。な拉，同時電着皮膜拉よび塗料を溶解した後 の酸化皮膜は，160 $170^{\circ} \mathrm{C} て ゙ 1 \mathrm{~h}$ 乾燥した。結果を表 2に示した。同時電着皮膜は耐了ルカリ性にとくにすぐ れ，1 h以上でも腐食は認められなかった。また，同じ 厚サのアミンアルカリ性皮膜 $(4 \mu)$ と塗料を溶解した 場合の皮膜 $(4 \mu)$ とでは, 後者が耐了ルカリ性执よび カタサともにすぐれていることを認めた。

\section{4. 結 論}

（1）アンモニアアルカリ性浴の場合

霆着塗料を共存させて陽極酸化を行ない，得られた同 時電着皮膜はヒッカキカタサ, 耐アルカリ性試験ともに アンモニアルカリ性皮膜より良好な結果を得た。

また，二段電解法 (I) 上り（II）のほうが，カタ

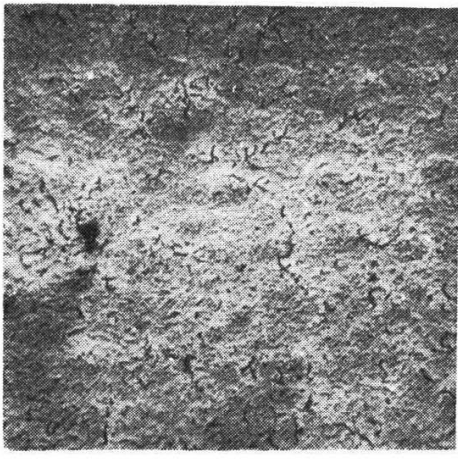

(a)アミンアルカリ皮膜

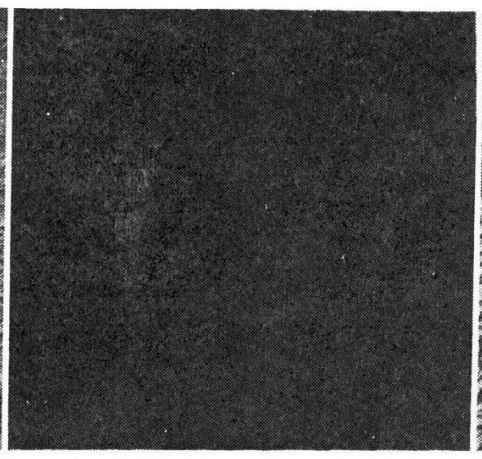

(b)同時電着皮膜 (アミンフルカ 1浴)

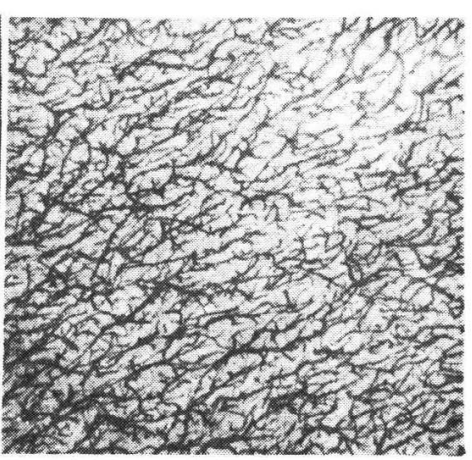

(c)整料溶解後の表面(アミン アルカリ浴)

写真 2 電子顕 微 鏡 写真

表 2 カタサ招よび耐アルカリ性試験結果

\begin{tabular}{|c|c|c|c|c|c|c|c|c|}
\hline \multirow[b]{4}{*}{ 試験法 } & \multicolumn{4}{|c|}{ アンモニアアルカリ皮膜1 } & \multirow{2}{*}{\multicolumn{4}{|c|}{ アミンアルカリ皮膜 }} \\
\hline & \multicolumn{2}{|c|}{ 三段電解㳎（I） } & \multicolumn{2}{|c|}{ 二段電解法（II） } & & & & \\
\hline & 単 独8 & 同時電1) & & 同特虽 & 同時電 & 着皮膜 ${ }^{2)}$ & 単 & 膜 ${ }^{3)}$ \\
\hline & 皮 膜 & 着皮膜 & 皮膜 & 着皮膜 & $\begin{array}{c}\text { 全 皮 膜 } \\
(11 \mu)\end{array}$ & $\begin{array}{c}\text { 酸化皮膜 } \\
(4 \mu)\end{array}$ & $11 \mu$ & $4 \mu$ \\
\hline ヒッカキカタサ & 16. 5 & 21.2 & 17.0 & 22.4 & 23.1 & 12.1 & 12.6 & 11.9 \\
\hline 耐 コルカ》性4) & $96.2 \%$ & $66.0 \%$ & $96.2 \%$ & $60.1 \%$ & $60 \mathrm{~min}$ 以上 & $35 \mathrm{~s}$ & $50 \mathrm{~s}$ & $30 \mathrm{~s}$ \\
\hline
\end{tabular}

1) 膜厚 $31 \pm 1 \mu$ を使用

2) 同時電着皮膜は160 $170^{\circ} \mathrm{C} て ゙ 1 \mathrm{~h}$ 焼付ヶ

3) 未封孔

4）アンモニアアルカリ皮膜は，10\% NaOH，20 $\mathrm{C} ， 3 \min$ 浸セキした場合の溶解量 アミンアルカリ皮膜は, J I Sの方法 
サ，耐アルカリ性ともにすぐれた結果を得，このこと は3. 8A/dm²で15min 電解を行なった場合のほうが，2 $\mathrm{A} / \mathrm{dm}^{2}$ で30min 電解を行なった場合に比べて，皮膜中 に塗料が多く共存していたためと考えられる。

（2）アミンアルカリ性浴の場合

第四アンモニウム塩を添加して, 塗料共存下で同時電 着を行なった場合，皮膜は二層より成り，表面に塗膜が アルミニウム素地側に酸化皮膜を形成していると考えら れる。塗料が $2 \%$ 場合は電解時間の経過により, 塗膜 層は徐々に増加するが，酸化皮膜層は20min 以後はほぼ 一定であった。しかし，共存塗料を減少さすことによ り，酸化皮膜層の膜厚を増加させることが可能であっ
た。また，赤外吸収曲線の結果より，この酸化皮膜層中 に少量の塗料が含有されていることが認められた。さら に, 同時電着皮膜は耐アルカリ性, ヒッカキカタサにと くにすぐれた結果を得た。

$$
\text { (1973-9-21 受理) }
$$

(昭和 46 年 11 月, 本協会第 44 回学術講演大会にて一部 発表)

\section{文献}

1) 吉村長蔵, 野口駿雄 ; 本誌, 23, 648 (1972)

2 ）吉村長蔵, 野口駿雄 ; 本誌, 22, 568 (1971)

3）木下脩；色材協会誌，44，273（1971）

\title{
電解エッチングによるクロムメッキの クラックの変化 ${ }^{\dagger}$
}

\author{
小 西 三 郎*・只 腰 光 章** \\ Change in Cracks of Chromium Deposits by Electroetching \\ Chromium Plating from Low Concentration $\mathrm{CrO}_{3}$ Baths (Part 14) \\ Saburo KONISHI and Mitsuaki TADAGOSHI
}

A continuous microscopic observation method for a certain definite point on the surface of electroetched chromium deposits was studied and the following results were obtained.

The width and number of cracks increased by etching, but cracks once produced never disappeared. When these cracks were observed with a scanning microscope, some cracks, which had come across a crack enlarged by etching, were more etched and developed in tunnel form.

Non-clear network patterns as well as clear cracks were observed with an optical microscope on the surface of bright chromium plating. These non-clear network patterns corresponded with the cracks produced by electroetching. Therefore, the non-clear patterns observed on the surface indicated all the cracks existing inside the chromium deposits.

†低濃度クロム酸溶液からのクロムメッキに関する研 究 (第14報)，前報（第13報）：金属表面技術，25, 97 (1974)

* 大阪府立工業技術研究所 (大阪府東大阪市高井田中 1-38)

Osaka Prefectural Industrial Research Institute.

** 奥野製薬工業秼（大阪府大阪市城東区放出中 1-48）

Okuno Chemical Industry Co., Ltd.

\section{1. まえがき}

クロムメッキを電解エッチングすれば，クラックが発 達することは以前からよく知られている。電解エッチン グにより発達したクラックはクロムメッキの性質の一端 を明らかにするばかりではなく，工業的にはポーラスク ロムメッキとして潤滑油をよく保持し，クロムメッキの 耐摩耗性がよくなるので, 航空機や船舶などの各種の内 燃機関に広く応用されている ${ }^{1) ~ 4) ~}$ 